\title{
Perilaku Panic Buying Mengiringi Kemunculan COVID-19? Sebuah Studi pada Awal Pandemi di Indonesia
}

\author{
Agung Minto Wahyu, Afifah Chusna Az Zahra, Muhammad Iqbal Fakhrul Firdaus, dan Aryudho \\ Widyatno \\ Fakultas Pendidikan Psikologi, Universitas Negeri Malang, Malang \\ e-mail: agungminto98@gmail.com, afifahchusna1@gmail.com,muhammadiqbal.fakhrulfirdaus@gmail.com, \\ dan aryudho.widyatno.fppsi@um.ac.id
}

\begin{abstract}
COVID-19 has an impact on society, one of which is panic buying. This study aims to get a comprehensive picture of panic buying behavior and factors that influence it in Indonesia,. The method in this research is a mixed-method which begins by distributing the survey to 418 respondents. The results obtained from the survey were then deepened using qualitative methods through interviews with six subjects. The results showed that panic buying occurred for several items that could potentially be urgently needed during a pandemic. This is in the background by the anxiety that accompanies society. However, for other items, purchases are still made in controlled conditions and as needed. The campaign not to carry out panic buying has not been fully effective. The biggest hope of the majority of the community is not in providing supplies of the goods needed, but rather for the government to increase speed in dealing with the spread of COVID-19.
\end{abstract}

Keywords: panic buying, COVID-19, pandemic, consumer behavior

\begin{abstract}
Abstrak
COVID-19 memiliki dampak bagi masyarakat salah satunya adalah panic buying. Penelitian ini bertujuan untuk mendapatkan gambaran secara komprehensif mengenai perilaku panic buying dan faktor-faktor yang memengaruhinya di Indonesia. Metode dalam penelitian ini adalah mixed-method yang diawali dengan menyebarkan survei kepada 418 responden. Hasil yang diperoleh dari survei kemudian diperdalam dengan metode kualitatif melalui wawancara kepada enam narasumber. Hasil penelitian menunjukkan bahwa panic buying terjadi pada beberapa barang yang berpotensi sangat dibutuhkan selama pandemi. Hal tersebut di latar belakangi oleh kecemasan yang menyertai masyarakat. Akan tetapi, pada barang yang lain pembelian masih dilakukan dalam kondisi terkontrol dan sesuai kebutuhan. Kampanye untuk tidak melakukan panic buying yang dilakukan belum sepenuhnya efektif. Harapan terbesar dari mayoritas masyarakat justru bukan pada penyediaan stok barang yang dibutuhkan, tetapi lebih cenderung agar pemerintah meningkatkan kecepatan dalam menangani penyebaran COVID-19 ini.
\end{abstract}

Kata kunci: panic buying, COVID-19, pandemi, perilaku konsumen 


\section{Pendahuluan}

Sejak ditetapkannya menjadi sebuah pandemi oleh World Health Organization (WHO, 2020), Corona Virus Diseases-19 (COVID-19) telah menjadi permasalahan bersama bagi seluruh negara-negara di dunia. Sebelum menjadi pandemi, COVID-19 dianggap sebuah wabah ketika jumlah kasus penyakit ini meningkat signifikan di Wuhan, Cina. Ketika penyebarannya mencapai wilayah geografis yang lebih luas, yaitu di seluruh wilayah Cina, maka COVID-19 dianggap sebagai epidemi. Hingga pada akhirnya saat ini menjadi pandemi ketika penularan penyakit ini tersebar di negara-negara lain (Lidwina, 2020). Menurut Widyaningrum (2020), pandemi sendiri identik dengan penyakit yang mampu menyebar ke banyak orang di beberapa negara dalam waktu yang sama. Penyebaran tersebut akan terjadi signifikan dan berkelanjutan secara global. Morens, Folkers dan Fauci, (2009) menyatakan terdapat beberapa kriteria yang harus dipenuhi untuk menetapkan sebuah penyakit menjadi pandemi baru, yaitu persebaran geografis yang luas, penularan penyakit yang tinggi, high attack rates and explosiveness, mayoritas populasi belum memiliki imunitas yang kuat, penyakit baru (novelty), infectiousness, contagiousness, severity.

WHO (2020) menyatakan bahwa pandemi COVID-19 bukan hanya permasalahan kesehatan saja, melainkan pandemi tersebut dapat menjadi permasalahan multi-sektor, seperti di bidang ekonomi, sosial, politik, hingga psikologis. Konsekuensi yang ditimbulkan juga tidak hanya sebatas konsekuensi kesehatan saja, melainkan juga konsekuensi dari berbagai sektor. WHO juga memberikan mandat kepada seluruh negara untuk bekerja dengan melibatkan banyak mitra di semua sektor. Lebih lanjut, WHO menekankan pada setiap individu harus terlibat dalam perjuangan melawan pandemi ini. Tujuannya adalah untuk mengurangi dampak yang ditimbulkan oleh pandemi ini.

Secara khusus, selama pandemi COVID-19 ini berlangsung telah menyebabkan munculnya panic buying yang dilakukan oleh sebagian besar masyarakat yang tinggal di wilayah pandemi. Fenomena panic buying ini terjadi dalam bentuk yang berbeda-beda di hampir semua negara yang terkena pandemi COVID-19 (La, dkk., 2020). Orang-orang di New 
York justru melakukan panic buying berupa anak ayam. Alasannya adalah agar nantinya dapat memiliki daging dan telur sendiri ketika tidak tersedia lagi di pasaran (Rossa \& Varwati, 2020). Hal serupa juga terjadi di North Carolina, bahkan panic buying yang terjadi adalah pembelian senjata api yang digunakan untuk melindungi diri ketika di masa mendatang terjadi aksi penjarahan dan perampokan (Solahuddin, 2020). Panic buying di Italia secara khusus justru terjadi pada bahan makanan pasta (Kwok, 2020). Di sisi lain, di Negara Inggris, Malaysia, Afrika Selatan, Jepang, Filipina, Singapura dan negara lainnya juga terjadi panic buying yang sebagian besar berupa pembelian bahan makanan, dan perlengkapan kesehatan (Januarta, 2020; Lappeman, 2020; Neo, 2020; Reuters, 2020; Southey, 2020)

Indonesia juga mengalami peristiwa panic buying yang sama. Sejak kemunculan pertama kali kasus COVID-19 di Indonesia pada 2 Maret 2020, fenomena panic buying juga terjadi di Indonesia. Sebagian besar masyarakat melakukan panic buying berupa kebutuhan pangan, masker, hand sanitizer, dan vitamin (Pingit, 2020). Dewan Penasihat Himpunan Penyewa Pusat Perbelanjaan Indonesia (HIPPINDO) menyatakan terdapat tiga periode panic buying yang terjadi di Indonesia. Pertama terjadi pada 2 Maret 2020 bertepatan ketika muncul kasus pertama COVID-19 di Indonesia. Kedua terjadi pada 14-16 Maret 2020 ketika mulai ada banyak instansi yang menghimbau untuk bekerja dari rumah. Ketiga terjadi pada 19 Maret 2020 ketika mulai gencar informasi mengenai rencana pemberlakuan lockdown (Putri, 2020). Salah satu toko retail terbesar di Indonesia menyatakan bahwa pada saat itu sebenarnya stok yang dimiliki masih sangat mencukupi, akan tetapi proses yang dibutuhkan untuk mendistribusikan barang dari gudang hingga terpajang membutuhkan waktu selama 1-2 hari. Hal tersebut seolah-olah membuat cemas masyarakat karena stok yang terpajang kosong (Pingit, 2020).

Fenomena panic buying yang terjadi menyebabkan sebagian besar negara membuat kebijakan-kebijakan yang dapat menanggulanginya. Salah satu kebijakan yang diterapkan di hampir semua negara adalah dengan membatasi jumlah pembelian. Hal tersebut diharapkan dapat menekan terjadinya pembelian dalam jumlah yang besar (Neo, 2020). Dalam hal ini, 
pelarangan untuk melakukan penimbunan barang juga otomatis menjadi kebijakan yang diterapkan (La, dkk., 2020). Di samping itu, pemerintah di setiap negara juga berusaha mengedukasi warganya agar tidak melakukan panic buying melalui berbagai media dan elemen. Pemerintah melakukan kerja sama dengan berbagai kalangan mulai dari pejabat pemerintah, tokoh masyarakat, hingga influencer di media sosial dalam kampanye tersebut (Dumont, 2020).

Selama pandemi sedang berlangsung, selain cemas dan takut untuk tertular penyakitnya, orang-orang juga cenderung mengalami kecemasan apabila tidak mendapatkan barang yang dibutuhkan untuk melindungi diri dari pandemi maupun barang-barang yang dibutuhkan untuk mempertahankan hidupnya di hari-hari mendatang. Peristiwa tersebut menjadi pemicu terjadinya panic buying (Taylor, 2019). Orang yang mengalami kecemasan berlebihan cenderung akan melakukan perilaku-perilaku untuk menjaga keselamatannya selama pandemi berlangsung juga secara berlebihan (Wheaton, dkk., 2012). Hal serupa juga berlaku ketika perilaku panic buying terjadi pada orang-orang dengan kecemasan berlebihan selama pandemi COVIC-19 berlangsung. Myers (2010) menyatakan bahwa terdapat gangguan kecemasan yang umum diderita oleh setiap individu ketika menghadapi sebuah stressor. Generalized anxiety disorder didefinisikan sebagai gangguan kecemasan di mana seseorang terus menerus tegang, gelisah, dan dalam keadaan rangsangan sistem saraf otonom. Meskipun bersifat umum, Myers (2010) menjelaskan bahwa gangguan kecemasan tersebut tetap memiliki gejala seperti terus-menerus merasa khawatir, tertekan, dan sering gelisah. Dalam konteks pandemi, gejala-gejala kecemasan tersebut yang dapat mendorong keputusan melakukan panic buying (Taylor, 2019).

Ketua Pusat Krisis Universitas Indonesia menyatakan bahwa perilaku panic buying di tengah pandemi tersebut juga dipicu oleh hilangnya sense of control dari masyarakat. Dalam kondisi tersebut, maka melakukan panic buying adalah bagian dari mekanisme psikologis yang dilakukan oleh masyarakat. Lebih lanjut, ketika pandemi COVID-19 semakin parah, maka 
akan memperkuat pemikiran akan kematian. Maka dari itu, individu akan dapat menjadi lebih impulsif, termasuk impulsif dalam membeli barang (Pelupessy, 2020).

Kondisi pada orang-orang yang berada di wilayah pandemi semakin diperparah dengan banyaknya informasi-informasi tidak valid yang beredar. Sebab selama masa pandemi berlangsung, banyak orang yang cenderung menggunakan media sosial untuk memperbaharui informasi dan mencari panduan-panduan untuk menghindari pandemi (Devine, Boluk \& Devine, 2017). Maka dari itu, media sosial dan berita real time yang non-stop beredar tanpa adanya filtrasi sangat berperan banyak pada terjadinya kerusuhan-kerusuhan sosial selama masa pandemi berlangsung. Kerusuhan sosial tersebut termasuk diantaranya yaitu panic buying (Hoegh, Ferreira \& Leman, 2016). Informasi atau rumor salah yang beredar tersebut membuat banyak orang akan cenderung melakukan pemikiran-pemikiran irasional dalam berbagai hal, termasuk dalam memutuskan untuk melakukan panic buying (Hou \& Du, 2020).

Apabila dilihat per individu, keputusan seseorang melakukan panic buying juga tidak dapat terlepas dari kajian keputusan pembelian dalam psikologi konsumen. Panic buying atau juga dikenal penimbunan konsumen adalah sebagai tindakan seseorang yang membeli produk dalam jumlah besar untuk menghindari kekurangan produk tersebut di masa depan. Salah satu alasan utama untuk melakukan panic buying adalah karena gangguan pasokan. Gangguan pasokan sendiri dapat terjadi karena berbagai faktor, seperti bencana alam, pemogokan buruh, maupun peraturan pemerintah. Gangguan pasokan tersebut dapat meningkatkan kecemasan konsumen mengenai ketersediaan pasokan di masa depan sehingga meningkatkan panic buying (Shou, Xiong dan Shen, 2011)

Shou, Xiong dan Shen (2011) menjelaskan lebih lanjut mengenai panic buying dalam kondisi sedang gangguan pasokan. Ketika penilaian konsumen terhadap suatu produk rendah, maka konsumen tersebut tidak akan membeli produk tersebut. Jika konsumen memiliki penilaian yang sedang terhadap suatu produk, maka konsumen tersebut akan membeli satu unit produk untuk setiap periode-nya. Di sisi lain, apabila konsumen memiliki penilaian yang tinggi terhadap suatu produk, maka konsumen tersebut cenderung akan menimbun produk tersebut 
melalui panic buying. Akan tetapi, penimbunan produk tersebut akan terjadi hanya jika biaya penyimpanannya rendah dan konsumen memiliki keyakinan akan kesulitan untuk mendapatkan produk tersebut di masa mendatang.

Penelitian terbaru mengenai panic buying selama COVID-19 ini berlangsung disebabkan karena melihat panic buying yang terjadi di negara lain sehingga menjadi role model bagi negara tersebut untuk melakukan hal yang sama. Selain itu, asosiasi yang kuat antara COVID-19 dengan SARS membuat sebagian besar orang juga menyamakan symtoms yang akan timbul yaitu seperti muntah dan diare. Maka dari itu, sebagian besar orang melakukan panic buying tisu toilet (Miri, dkk., 2020). Sejalan dengan penelitian tersebut, Taylor (2019) menyatakan bahwa perilakuka panic buying dapat menular pada orang lain di sekitarnya. Di sisi lain, beberapa penyebab kasus panic buying di Cina justru disebabkan oleh kesalahan informasi yang sudah terlanjur beredar di publik. Misalnya disinformasi yang mengatakan bahwa bawang putih dapat menjadi obat COVID-19, hal tersebut memicu terjadinya panic buying pada bawang putih. Klarifikasi yang dilakukan oleh pemerintah adalah cara efektif untuk mengurangi perilaku irasional tersebut (Hou \& Du, 2020).

Berbeda dengan penelitian sebelumnya, hasil penelitian La dkk., (2020) menyatakan bahwa panic buying warga Hanoi tidak berlangsung lama karena pemerintah setempat berhasil meyakinkan warganya bahwa pasokan terhadap barang-barang yang diperlukan akan cukup. Lebih lanjut, kesiapan sejak dini dari warga Hanoi dalam merespon COVID-19 ini juga karena melakukan proses penyaringan yang tepat mengenai informasi mengenai COVID-19 dari Cina. Selain itu, tidak terjadinya panic buying di beberapa negara disebabkan karena kebiasaan warganya yang sebelumnya memang sering menggunakan masker wajah atau hand sanitizer. Hasil penelitian Ho, Chee dan Ho (2020) menyatakan bahwa strategi untuk meyakinkan warganya mengenai ketersediaan pasokan barang-barang yang dibutuhkan juga diterapkan oleh Singapura. Hal tersebut digunakan untuk menunjukkan kepada warganya bahwa negara telah siap menghadapi pandemi COVID-19. Harapannya adalah dapat menurunkan kecemasan warganya yang menjadi penyebab panic buying. 
Belum ada penelitian yang pasti mengenai faktor yang mendasari perilaku panic buying di Indonesia. Jika dikaitkan dengan kajian psikologi lintas budaya, sangat memungkinkan apabila panic buying di Indonesia dilandasi oleh faktor-faktor pendorong yang berbeda dengan negara-negara lain. Menurut Matsumoto (2004), perbedaan budaya dapat menyebabkan perbedaan akan pemahaman tentang kebenaran dan prinsip-prinsip yang berlaku. Maka dari itu, perbedaan budaya tersebut sangat memungkinkan menjadi penyebab terjadinya perbedaan faktor yang mendasari perilaku panic buying di Indonesia. Hal tersebut sebenarnya juga tercermin dari ulasan sebelumnya mengenai penyebab perilaku panic buying selama berlangsungnya pandemi COVID-19 di berbagai negara di dunia, yaitu hasil penelitian yang dilakukan di masing-masing negara mengenai perilaku panic buying memiliki hasil yang berbeda-beda.

Berdasarkan uraian-uraian sebelumnya, penelitian ini dilakukan untuk melakukan studi kasus mengenai penyebab terjadinya perilaku panic buying di Indonesia. Tujuannya adalah untuk mendapatkan gambaran secara utuh mengenai perilaku panic buying di Indonesia. Hasil penelitian ini diharapkan agar dapat menjadi bahan evaluasi dalam mengatasi perilaku panic buying selama pandemi COVID-19 ini berlangsung. Selain itu, melalui penelitian ini juga diharapkan dapat memunculkan rekomendasi-rekomendasi yang dapat dilakukan agar dapat menekan terjadinya perilaku panic buying, baik pada masa pandemi COVID-19 sekarang, maupun ketika terjadi peristiwa-peristiwa serupa di masa mendatang.

\section{Metode Penelitian}

Penelitian ini menggunakan mixed methods tipe explanatory sequential design yang diawali dengan pengumpulan data kuantitatif dan dilanjutkan pengumpulan data kualitatif untuk membantu menganalisis data kuantitatif, sehingga hasil penelitian dengan desain ini bersifat menjelaskan suatu gambaran umum (generalisasi) (Creswell \& Clark, 2011). Penelitian kuantitatif menggunakan survey untuk mengetahui gambaran umum mengenai panic buying pada masyarakat Indonesia. Melalui teknik accidental sampling diperoleh responden penelitian 
sebanyak 418 orang yang tersebar di berbagai provinsi yang ada di Indonesia. Analisis data yang digunakan dalam metode survey ini adalah analisis deskriptif.

Setelah menemukan gambaran umum mengenai panic buying di Indonesia, peneliti melakukan penggalian data lebih mendalam dengan menggunakan metode kualitatif dengan jenis studi kasus. Pendekatan kualitatif digunakan untuk dapat menjawab pertanyaan dalam penelitian dimana mengharuskan peneliti untuk melakukan eksplorasi secara mendalam terhadap masalah yang diajukan (Herdiansyah, 2015). Pengumpulan data kualitatif dilakukan dengan melakukan wawancara secara mendalam kepada enam narasumber yang berasal dari responden penelitian kuantitatif. Akan tetapi, satu dari enam narasumber tidak memenuhi kriteria yaitu telah melakukan panic buying selama pandemi. Oleh karena itu, hanya informasi dari lima narasumber yang digunakan dalam penelitian ini.

Peneliti juga mewawancarai 2 informan untuk memverifikasi kembali pernyataanpernyataan dari narasumber. Hal itu dilakukan untuk menjaga keandalan dari penelitian ini. Teknik analisis data dalam penelitian ini menggunakan model interaktif yang terdiri dari pengumpulan data, reduksi data, display data, dan penarikan kesimpulan (Miles, Huberman \& Saldana, 2014)

\section{Hasil Penelitian}

\subsection{Profil Responden}

Berdasarkan hasil survei yang disebarkan ke seluruh Wilayah Indonesia, profil responden dalam survei terbagi menjadi beberapa karakteristik. Usia responden didominasi oleh remaja akhir yang berusia antara 19-21 tahun sebanyak 54,6\%, kemudian diikuti secara berurutan oleh dewasa awal $(23,4 \%)$, remaja menengah $(11,7 \%)$, dewasa menengah $(7,4 \%)$, remaja awal $(1,9 \%)$, dan dewasa akhir (1\%). Tingkat pendidikan dari keseluruhan responden didominasi oleh lulusan SMA sebanyak 65,1\%. Kemudian disusul oleh S1 (27,3\%), S2 (3,8\%), SMP $(1,7 \%)$, diploma $(1,4 \%)$, SD $(0,7 \%)$. Keseluruhan responden tersebut berasal dari 14 
profesi yang berbeda. Jenis profesi tersebut didominasi oleh mahasiswa $(74,6 \%)$, pegawai negeri $(8,4 \%)$, pegawai swasta $(5,5 \%)$, dan profesi lainnya $<5 \%$.

Sementara profil enam narasumber dan dua informan wawancara terbagi menjadi beberapa karakteristik. Enam narasumber rata-rata didominasi oleh dewasa awal yang berusia 20-30 tahun dengan persentase $80 \%$, diikuti dengan usia dewasa akhir yang berkisar antara 40-65 tahun sebanyak 20\%. Tingkat pendidikan terakhir narasumber didominasi oleh lulusan SMA sebanyak $80 \%$, kemudian diikuti S1 dengan tingkat persentase $20 \%$. Keseluruhan narasumber memiliki 3 profesi yang berbeda diantaranya mahasiswa (40\%), karyawan swasta (40\%), dan ibu rumah tangga (20\%). Profil informan secara keseluruhan berusia 20-30 tahun dengan tingkat pendidikan S2. Kedua informan tersebut berprofesi sebagai dosen.

\subsection{Hasil Survei}

Sebelum masuk pada perilaku panic buying yang dilakukan oleh masyarakat. Survei ini terlebih dahulu mengukur tingkat kecemasan masyarakat mengenai adanya pandemi COVID19. Hasilnya menunjukkan bahwa sebagian masyarakat merasa cemas dengan adanya pandemi COVID-19. Kecemasan yang dirasakan sebelumnya sejalan dengan dampak pemberitaan mengenai COVID-19 di media massa terhadap kondisi psikologis masyarakat, dimana hasil surveinya menunjukkan bahwa 47,1\% masyarakat mengalami kecemasan. Bahkan 9,6\% lainnya merasakan cemas yang sangat parah.

Pengetahuan masyarakat menunjukkan bahwa 60,5\% masyarakat sangat mengetahui panic buying dan $33,5 \%$ pernah mendengarnya. Hanya ada $6 \%$ masyarakat yang tidak mengetahui. Bahkan 93,1\% masyarakat sebenarnya sangat meyakini bahwa panic buying dapat berdampak pada kinerja tenaga medis karena berpotensi kekurangan Alat Pelindung Diri (APD), dan kenaikan harga di pasaran. Maka dari itu, sebagian besar masyarakat menganggap bahwa panic buying bukanlah hal yang wajar untuk dilakukan selama pandemi COVID-19 ini berlangsung. 
Hasil survei menunjukkan bahwa 67\% Masyarakat Indonesia tidak pernah melakukan perilaku panic buying selama pandemi COVID-19. Akan tetapi, ketika pertanyaan dalam survei diberikan dengan diksi yang lain yaitu "panic buying" diganti dengan "pembelian dalam jumlah banyak", maka jawaban yang diberikan responden justru berbeda. Sebagian besar responden bahkan mampu memberikan alasan-alasan tertentu sehingga memilih melakukan panic buying. Hal tersebut menunjukkan adanya inkonsistensi dengan hasil sebelumnya yang menyatakan bahwa sebagian besar masyarakat tidak melakukan panic buying. Sebanyak 53,9\% masyarakat beralasan melakukan panic buying karena ingin mengantisipasi jika diberlakukan lockdown di masa depan, kemudian diikuti oleh kelima alasan lainnya, yaitu untuk mengantisipasi kenaikan harga, mendapatkan ketenangan, mengikuti trend yang terjadi, memenuhi kebutuhan yang memang diperlukan, hingga untuk kebutuhan dijual kembali. Di sisi lain, terdapat $16,7 \%$ yang tidak menjawab secara spesifik alasannya dalam melakukan panic buying.

Perasaan yang dirasakan oleh masyarakat setelah melakukan panic buying cukup beragam, diantaranya yaitu $42 \%$ merasa tenang setelah melakukan panic buying, di sisi lain sebanyak 27,1\% justru merasa bersalah setelah melakukan panic buying. Dorongan yang membuat seseorang melakukan panic buying dari hasil survei menyatakan bahwa sebesar 59,5\% seseorang melakukan panic buying karena dorongan pribadi. Kemudian diikuti dengan dorongan yang berasal dari media sosial $(17,1 \%)$, keluarga $(15,2 \%)$, serta televisi $(5,6 \%)$, tetangga $(1,5 \%)$, teman $(0,7 \%)$, dan ajaran agama $(0,4 \%)$. Sebagian besar masyarakat melakukan panic buying untuk membeli barang yang dapat digunakan oleh keluarganya $(68,2 \%)$. Kemudian sisanya untuk orang lain yang membutuhkan $(18,5 \%)$, murni untuk diri sendiri (12,3\%), teman dekat (0,6\%), serta akan dijual kembali (0,3\%). Lebih lanjut, masyarakat melakukan panic buying berupa sembako $(60,2 \%)$, vitamin $(11,6 \%)$, dan masker $(11,3 \%)$. Di sisi lain, tempat masyarakat melakukan panic buying tersebut sangat terkait erat dengan jenis barang yang di beli oleh sebagian besar masyarakat sebelumnya. Sebab minimarket $(45,8 \%)$, pasar $(26,1 \%)$, online shop $(13,7 \%)$, dan apotek $(6,7 \%)$ merupakan empat 
tempat paling sering digunakan untuk melakukan panic buying. Keempat tempat tersebut menyediakan barang-barang yang paling sering dilakukan panic buying oleh masyarakat sebelumnya.

Hasil survei menunjukkan bahwa tidak terdapat faktor yang mampu mendorong munculnya perilaku panic buying pada masyarakat. Untuk mendapatkan gambaran perilaku panic buying secara lebih mendetail, peneliti menggali faktor-faktor tersebut melalui proses wawancara yang mendalam dengan beberapa narasumber dalam penelitian kualitatif. Di sisi lain, masyarakat memiliki harapan yang beragam kepada pemerintah dalam mengatasi perilaku panic buying yang ada. Masyarakat menginginkan agar pemerintah memberikan kepastian mengenai ketersediaan stok barang di pasaran $(29,4 \%)$ serta menyediakan bantuan-bantuan sosial yang diberikan kepada masyarakat $(15,8 \%)$.

\subsection{Hasil Wawancara}

Kecemasan yang dirasakan selama pandemi COVID-19 bergantung pada kemampuan coping masing-masing individu. Hasil wawancara menunjukkan kelima subjek merasakan kecemasan selama pandemi COVID-19, sedangkan satu subjek lainnya merasa biasa saja dan bahkan cenderung tidak merasakan kecemasan sehingga tidak mengalami panic buying. Maka dari itu, paparan dalam hasil penelitian ini merupakan hasil wawancara yang diperoleh dari kelima subjek narasumber cemas saja. Kecemasan subjek penelitian selama pandemi ditunjukkan dengan perasaan panik dan cemas ketika COVID-19 menyebar di Indonesia. Hal tersebut terjadi karena masyarakat mengembangkan perasaan takut untuk terinfeksi oleh virus ini. Kecemasan tersebut juga diperparah oleh adanya pemberitaan COVID-19 melalui televisi, media sosial, dan media digital lainnya.

Kecemasan akibat pandemi COVID-19 ini dapat berakibat pada rasa takut untuk berinteraksi dengan orang lain. Kelima subjek penelitian mengungkapkan bahwa dirinya merasa sangat cemas ketika berinteraksi dengan orang lain meskipun itu teman sendiri sehingga subjek membatasi berhubungan dengan orang lain. Jika memang dirasa terpaksa 
harus berhubungan dengan orang lain, maka subjek memilih untuk menerapkan protokol kesehatan seperti jaga jarak minimal 1 meter, memakai masker, mencuci tangan, dan memakai hand sanitizer. Kecemasan dalam berhubungan dengan orang lain karena takut tertular tersebut membuat kelima subjek juga menjadi takut ketika harus berpergian ke tempat keramaian.

Selama pandemi COVID-19 ini, tempat-tempat keramaian yang paling sering dikunjungi oleh subjek adalah tempat perbelanjaan seperti mall, swalayan, dan minimarket. Rasa cemas yang dirasakannya selama pandemi COVID-19 diakui subjek dapat mempengaruhi perilaku belanjanya. Temuan wawancara menunjukkan bahwa keempat subjek merasa jika kecemasan selama pandemi mendorong perilaku belanja sedangkan satu subjek lainnya tidak merasa perilaku belanjanya dipengaruhi oleh rasa cemas, tetapi lebih banyak dipengaruhi oleh dorongan oleh orang-orang terdekatnya yang mengalami kecemasan. Keempat subjek yang didorong kecemasan internal tadi akan mendapatkan rasa tenang setelah membeli barang yang dirasa penting untuk dimiliki di masa pandemi ini. Selain itu, kekhawatiran untuk kehabisan stok barang terutama barang yang dianggap sangat dibutuhkan selama pandemi COVID-19, seperti masker dan hand sanitizer juga memicu perilaku panic buying. Hal tersebut didukung dengan temuan penelitian kuantitatif yaitu dimana subjek melakukan pembelian dalam jumlah banyak karena ingin memuaskan rasa ketenangan, memenuhi keinginan diri sendiri, takut harga barang yang dibutuhkan naik pesat, khawatir kehabisan suatu barang, takut tidak bisa keluar (karena PSBB), dan faktor kebutuhan. Barang-barang yang biasanya dibeli oleh subjek adalah kebutuhan pokok (beras, mie, minyak, sabun, dan lain-lain), make up, hingga aitem game pada gawai.

Setelah melakukan pembelian dalam jumlah banyak, keempat subjek yang melakukan panic buying karena kecemasan internal menjadi merasa senang, nyaman, puas, dan tenang karena stok kebutuhan sehari-hari terpenuhi hanya dengan sesekali keluar rumah, tetapi timbul sedikit penyesalan karena uang subjek terkuras habis. Tak hanya subjek, temuan penelitian ini juga menunjukkan bahwa sebagian orang di sekitar subjek juga melakukan pembelian dalam jumlah banyak, terutama pada usia dewasa. Hal tersebut banyak dilatarbelakangi oleh 
keinginan untuk meminimalisasi frekuensi bepergian ke luar rumah, terlebih di sebagian daerah dengan pengawasan dan perizinan keluar-masuk yang cukup ketat. Selain kebutuhan pokok, barang yang dibeli adalah alat pelindung diri seperti masker dan hand sanitizer, padahal sebelum pandemi, alat tersebut tidak begitu diperlukan.

Selain untuk meminimalisasi frekuensi bepergian ke luar rumah, temuan penelitian ini menunjukkan bahwa subjek melakukan pembelian dalam jumlah banyak karena dipengaruhi informasi yang ada di media massa, seperti informasi kenaikan harga bahan pokok, promosi produk (seperti bahan pemutih pakaian sebagai campuran disinfektan), serta berita perkembangan pandemi COVID-19 yang membuat subjek semakin khawatir. Namun, peneliti menemukan sebagian subjek yang melakukan pembelian dalam jumlah banyak karena inisiatif pribadi dan keluarga. Terkait dorong eksternal untuk melakukan panic buying, kebanyakan subjek menyatakan bahwa media sosial menjadi media yang paling bisa memengaruhi masyarakat sehingga memicu untuk melakukan panic buying. Akan tetapi ada juga yang merasa bahwa tidak semua media bisa mempengaruhi perilaku individu, sebab semua kembali pada masing-masing individu tersebut.

Temuan penelitian ini menunjukkan bahwa kampanye dari berbagai institusi, baik institusi pemerintah maupun NGO (non-government organization) di media sosial untuk tidak berbelanja dalam jumlah banyak cukup efektif bagi calon konsumen yang memiliki pengetahuan dan kesadaran terhadap dampak negatif dari panic buying. Akan tetapi kampanye tersebut bisa jadi tidak efektif karena beberapa hal, seperti ketakutan masyarakat yang masih tinggi, kebutuhan calon konsumen yang kian mendesak, serta atensi sebagian masyarakat yang masih kurang terhadap pesan-pesan di media sosial.

Di akhir wawancara, subjek tidak hanya memberikan harapan kepada pemerintah untuk mengendalikan pembelian dalam jumlah banyak, tetapi juga mengajukan berbagai langkah konkret agar dapat mengurangi panic buying, seperti penambahan pajak di setiap item barang, penjagaan terhadap ketersediaan stok barang pokok, tidak ada pembatasan yang mempersulit aktivitas belanja individu, meningkatkan kesadaran masyarakat untuk membatasi pembelian 
kebutuhan tersier, dan pemerataan distribusi barang pokok di setiap daerah. Walau demikian, salah satu subjek merasa bahwa pembatasan pembelian yang dilakukan oleh pemerintah cukup efektif, sehingga perilaku pembelian masyarakat lebih terkendali.

\section{Pembahasan}

Pada awal pandemi COVID-19 sebagian besar subjek merasa kesulitan mendapatkan masker dan hand sanitizer yang diperlukan untuk melindungi diri dan keluarganya, terutama ketika harus bepergian keluar rumah. Selain masker dan hand sanitizer, masyarakat Indonesia juga melakukan panic buying pada bahan-bahan sembako. Maka dari itu, banyak pusat perbelanjaan yang mengalami kelangkaan stok sembako. Sebagai ilustrasi, salah satu subjek menyatakan bahwa ketika akan membeli salah satu bahan makanan, subjek harus berebut dengan pembeli lain yang memborong bahan makanan tersebut. Hal tersebut membuat harga sembako semakin naik. Sejalan dengan penelitian Aprilia (2021) yang menjelaskan bahwa masyarakat Indonesia justru banyak melakukan panic buying dengan membeli bahan makanan pokok berupa sembako, sedangkan pembelian APD menjadi prioritas kedua untuk dibeli. Hal itu relevan dengan sebagian karakteristik masyarakat Indonesia yang merasa aman ketika memiliki stok cukup dalam persediaan makanan untuk beberapa waktu ke depan (Rosita, 2020). Penimbunan barang yang dilakukan oleh individu atau masyarakat dalam situasi gawat atau darurat seringkali disebut dengan istilah panic buying. Menurut Lubis, dkk., (2013), panic buying dapat disebabkan oleh kurang komprehensifnya informasi yang diterima oleh masyarakat. Masyarakat juga menjadi korban dari disinformasi seperti adanya rumor terjadinya lockdown di waktu dekat, hingga rumor terkait kenaikan harga secara drastis pada berbagai kebutuhan primer dan perlengkapan protokol kesehatan. Dampaknya, muncul kekhawatiran di masyarakat sehingga perilaku belanja masyarakat menjadi pasif-agresif sebagai bentuk mekanisme pertahanan diri. Terdapat dua kekhawatiran yang muncul di masyarakat. Pertama, kekhawatiran apabila tidak belanja hari ini, maka harga barang di esok hari bisa naik. Kedua, jika tidak belanja hari ini, maka barang tersebut akan habis di esok hari. Demikianlah kondisi 
panic buying yang saat ini terjadi, terutama untuk kebutuhan pokok dan alat pelindung diri (Soenjoto \& Mujiyono, 2020).

Dari hasil wawancara, salah satu subjek menyatakan bahwa semakin banyak individu yang mencari suatu barang, seperti alat pelindung diri, maka permintaan terhadap suatu barang tersebut akan semakin besar. Sebagaimana hukum demand and supply dalam ilmu ekonomi menyatakan bahwa apabila terjadi permintaan yang tinggi, maka jumlah persediaan barang akan semakin sedikit dan harga barang akan semakin tinggi (Febianti, 2014). Faktor tersebut yang dimanfaatkan oleh sebagian penjual yang mencari keuntungan lebih dalam situasi seperti saat ini karena dalam kondisi darurat, masyarakat cenderung membeli barang melampaui kebutuhan. Semakin banyak individu yang melakukannya, maka akan terjadi kelangkaan barang karena disekuilibrium antara demand dan supply (Aisyah, 2020). Kelangkaan akibat dis-ekuilibrium demand dan supply dapat mengakibatkan kenaikan harga (Kewal, 2012)

Untuk mengantisipasi dan mencegah terjadinya panic buying, salah satu subjek menyatakan bahwa masyarakat tentu membutuhkan kejelasan informasi dari pihak berwenang. Pernyataan tersebut sesuai dengan pendapat Wahyudi (2020) bahwa informasi yang diberikan oleh pemerintah tidak boleh sampai tumpang tindih. Idealnya, informasi yang diterima oleh masyarakat seharusnya mampu mengendalikan tekanan psikologis masyarakat, terutama yang disebabkan oleh merebaknya hoax. Selain itu, salah satu subjek menyatakan bahwa langkah konkret lain yang dapat dilakukan oleh pemerintah adalah pembagian alat pelindung diri secara gratis kepada masyarakat di berbagai tempat, seperti di pusat keramaian, perkantoran, dan lembaga pendidikan, sebagaimana yang telah dilakukan sebelumnya ketika terjadi bencana alam, agar masyarakat tidak meresahkan ketersediaan masker di pasaran, serta memperkecil kesempatan bagi penimbun barang.

Secara psikologis, Pelupessy (2020) memaparkan bahwa merebaknya COVID-19 menguatkan pikiran setiap individu akan kematian. Ketakutan akan kematian tersebut menjadi salah satu sumber stres utama di awal pandemi. Ketika manusia diingatkan tentang kefanaan tersebut, maka individu dapat menjadi lebih impulsif. Bentuk impulsivitas yang banyak 
ditampilkan oleh masyarakat yaitu dengan melakukan panic buying. Didukung pendapat Taylor (2019) yang menyatakan bahwa salah satu alasan psikologis yang menyebabkan individu melakukan panic buying merupakan kecemasan yang disebabkan oleh risiko yang mungkin saja dialami di masa mendatang. Kecemasan yang dirasakan oleh pelaku panic buying akan berkurang ketika risiko yang disebabkan oleh suatu krisis sedikit berkurang karena mereka telah menyediakan berbagai bahan pokok yang dapat digunakan dalam jangka panjang. Keinginan untuk mencegah risiko melalui panic buying dapat disebabkan oleh kecemasan dalam diri, selain karena upaya untuk menghindari krisis. Meskipun panic buying tidak pernah dibenarkan oleh pemerintah, pelaku panic buying melakukan tindakan tersebut karena toleransi risiko mereka cukup rendah, sehingga mereka merasa perlu menimbun bahan-bahan pokok untuk menenangkan diri mereka (Arafat, Kar, \& Kabir, 2020). Ye, dkk (2020) menyatakan bahwa dalam kasus bencana alam atau situasi darurat lainnya, terdapat perbedaan yang jelas antara pembelian yang bertujuan untuk mengantisipasi bencana atau pembelian yang semata bertujuan untuk menimbun barang. Namun, dalam pandemi COVID-19, terdapat banyak ketidakpastian yang memicu terjadinya perilaku panic buying atau pembelian berlebih. Salah satu subjek menyatakan bahwa panic buying pada masyarakat disebabkan oleh kecemasan dan keinginan untuk menghentikan kecemasan tersebut. Hal tersebut sesuai dengan pernyataan Loxton dkk. (2020) bahwa panic buying dapat membantu individu untuk mengendalikan situasi, karena dalam situasi darurat, individu merasa perlu melakukan sesuatu sesuai tingkatan krisis yang disadari.

Menurut Loxton, dkk. (2020), persiapan diri untuk menjalani masa isolasi atau keterasingan bukan merupakan manifestasi dari kecemasan ekstrem yang irasional, melainkan suatu ekspresi dari mekanisme survival yang telah mengakar dalam diri manusia. Namun dalam konteks pembelian bahan makanan, individu juga tidak perlu terburu-buru membeli berbagai bahan makanan yang tidak bisa bertahan lama, dan sebaiknya membuat daftar belanja sebelum membeli bahan makanan sesuai kebutuhan (Pawlick, 2012). Memang, panic buying atau buying on demand menjadi hak konsumen, tetapi alangkah baiknya tetap mempedulikan hak 
orang lain untuk mengakses suatu barang. Sebab, panic buying cenderung menguntungkan penimbun barang dan merugikan individu yang benar-benar membutuhkan (Zingales, 2012).

Courtice (2020) memaparkan bahwa bagi sebagian individu, perilaku hidup bersih dan sehat seperti mencuci tangan tampak terlalu biasa untuk merespon peristiwa luar biasa seperti pandemi COVID-19. Oleh sebab itu, sebagian individu perlu memberikan respon yang dramatis pula, salah satunya dengan melakukan panic buying untuk melindungi diri sendiri. Meskipun demikian, Matlin (2013) menyatakan bahwa dalam menghadapi ancaman yang tidak diketahui, manusia cenderung menggunakan pengetahuan yang telah dimiliki ketika menghadapi ancaman serupa sebelumnya .

Menurut Roberts dan Tehrani (2020), sebagian individu mengaitkan pandemi COVID19 dengan pandemi SARS yang sama-sama disebabkan oleh coronavirus pada 2003. Selain itu, individu akan menghubungkan COVID-19 dengan black plague yang sempat menjangkiti Eropa sehingga cenderung dapat membesar-besarkan risiko yang akan terjadi. Hal senada juga diungkapkan oleh Zwart (2020). Menurutnya, manusia memiliki kemampuan untuk memperkirakan ancaman yang akan terjadi di masa depan, serta mempersiapkan diri untuk menghadapinya. Dalam kasus pandemi COVID-19, kecepatan penyebaran informasi juga mempengaruhi langkah antisipasi yang dilakukan individu.

\section{Simpulan dan Saran}

Sebagian masyarakat merasakan kecemasan selama pandemi COVID-19. Salah satu penyebab terjadinya gangguan psikologis seperti kecemasan adalah pemberitaan di media massa. Kecemasan ini dapat mendorong sebagian masyarakat untuk melakukan panic buying. Studi ini menunjukkan bahwa kecemasan yang dirasakan selama pandemi COVID-19 berlangsung mempengaruhi perilaku belanja. Perilaku panic buying dilakukan sebagian masyarakat sebagai bentuk antisipasi apabila diberlakukan lockdown. Perilaku panic buying di Indonesia sebagian besar sama dengan yang terjadi di luar negeri, yaitu terjadi pada bahan- 
bahan untuk protokol kesehatan. Akan tetapi, Masyarakat Indonesia juga banyak yang melakukan panic buying pada bahan makanan pokok.

Faktor pendorong munculnya panic buying di Indonesia diantaranya ketakutan akan kenaikan harga barang, takut kehabisan stok barang, khawatir terjadi PSBB ulang, memenuhi keinginan diri sendiri, memuaskan rasa ketenangan, dan faktor kebutuhan. Faktor-faktor tersebut juga hampir sama dengan faktor yang melatarbelakangi perilaku panic buying di berbagai negara lain. Untuk mengantisipasi adanya perilaku panic buying, masyarakat berharap kepada pemerintah agar melakukan tindakan cepat dalam menangani COVID-19, memastikan ketersediaan stok barang di pasaran, dan menyediakan bantuan-bantuan sosial pada masyarakat.

\section{Daftar Pustaka}

Aisyah, S. A. M. (2020). Dampak COVID-19 terhadap Praktik Jual-beli. Al-Muamalat: Jurnal Hukum dan Ekonomi Syariah, 5(1), 27-47.

Aprilia, C. S. (2021). Perilaku Panic Buying dan Berita Hoaks Covid-19 di Kota Bandung. Jurnal Communio: Jurnal Jurusan Ilmu Komunikasi, 10(1), 11-26.

Arafat, S. M. Y., Kar, S. K., \& Kabir, R. (2020). Possible Controlling Measures of PanicBuying During COVID-19. International Journal of Mental Health and Addiction, 1-3.

Courtice, D. P. (2020). COVID-19 and Creating The Future We Want. In Advances in Global Leadership. Bingley: Emerald Group Publishing Ltd.

Creswell, J. W., \& Clark, V. L. P. (2011). Designing and Conducting Mixed Methods Research (2nd Editio). California: SAGE Publication.

Devine, A., Boluk, K., \& Devine, F. (2017). Managing Social Media during a Crisis: A Conundrum for Event Managers. Event Management, 21, 375-389. https://doi.org/10.3727 /152599517X14998876105729 
Dumont, J. (2020). The Giant Company Takes to Social Media to Stop Panic Buying. (Online), (https://www.grocerydive.com/news/the-giant-company-takes-to-social-media-to-stoppanic-buying/574969/), diakses pada 28 Februari 2021.

Febianti, Y. N. (2014). Permintaan dalam Ekonomi. Edunomic, 2(1), 15-24.

Herdiansyah, H. (2015). Metodologi Penelitian Kualitatif dalam Ilmu Psikologi. Jakarta: Salemba Empat.

Ho, C. S., Chee, C. Y., \& Ho, R. C. (2020). Mental Health Strategies to Combat the Psychological Impact of COVID-19 Beyond Paranoia and Panic. Ann Acad Med Singapore, 49(1), 1-3.

Hoegh, A., Ferreira, M. A. R., \& Leman, S. (2016). Spatiotemporal Model Fusion: Multiscale Modelling of Civil Unrest. Journal of the Royal Statistical Society. Series C: Applied Statistics. https://doi.org/10.1111/rssc.12138

Hou, Z., \& Du, F. (2020). Assessment of Public Attention, Risk Perception, Emotional and Behavioural Responses to the COVID-19 Outbreak: Social Media Surveillance in China. (Online), (https://www.medrxiv.org/content/10.1101/2020.03.14.20035956v1.articleinfo), diakses pada 28 Februari 2021.

Januarta, F. (2020). Panic Buying In Malaysia as COVID-19 Confirmed Cases Increasing.(Online), (https://en.tempo.co/photo/79074/panic-buying-in-malaysia-ascovid-19-confirmed-cases-increasing), diakses pada 28 Februari 2021.

Kewal, S. S. (2012). Pengaruh Inflasi, Suku Bunga, Kurs, dan Pertumbuhan PDB terhadap Indeks Harga Saham Gabungan. Jurnal Economia, 8(1), 53-64.

Kwok, C. (2020). Coronavirus Panic Buying Boosts Pasta Production in Italy. (Online), (https://www.scmp.com/video/coronavirus/3078069/coronavirus-panic-buying-boostspasta-production-italy), diakses pada 28 Februari 2021.

La, V.-P., Pham, T.-H., Ho, T., Hoang, N., Linh, N., Trang, V. T., Vuong, Q.-H. (2020). Policy 
Response, Social Media and Science Journalism for The Sustainability of The Public Health System Amid COVID-19 Outbreak: The Vietnam Lessons. (Online), (https://ideas.repec.org/p/osf/socarx/cfw8x.html), diakses pada 1 Marwt 2021.

Lappeman, J. (2020). Panic Buying in the Wake of COVID-19 Underscores Inequalities in South Africa. (Online), (https://theconversation.com/panic-buying-in-the-wake-of-covid19-underscores-inequalities-in-south-africa-134172), diakses pada 1 Maret 2021.

Lidwina, A. (2020). Covid-19, dari Wabah Jadi Pandemi. (Online), (https://katadata.co.id/ariayudhistira/infografik/5e9a42145752b/covid-19-dari-wabahjadi-pandemi), diakses pada 28 Februari 2021.

Loxton, M., Truskett, R., Scarf, B., Sindone, L., Baldry, G., \& Zhao, Y. (2020). Consumer Behavior During Crisis: Preliminary Research on How Coronavirus Has Manifested Consumer Panic Buying, Herd Mentality, Changing Discretionary Spending, and The Role of The Media in Influencing Behavior. Journal of Risk and Financial Management, $13(8), 166$.

Lubis, A. N., Sadalia, I., Fachrudin, K. A., \& Meliza, J. (2013). Perilaku Investor Keuangan. Medan: USU Press.

Matlin, M. W. (2013). Cognition (8th ed.). Unites States of America: John Willey \& Sons, Inc.

Matsumoto, D. (2004). Pengantar Psikologi Lintas Budaya. Yogyakarta: Pustaka Belajar.

Miles, M. B., Huberman, A. M., \& Saldana, J. (2014). Qualitative Data Analysis: A Methods Sourcebook. USA: Sage Publications.

Miri, S. M., Roozbeh, F., Omranirad, A., \& Alavian, S. M. (2020). Panic of Buying Toilet Papers: A Historical Memory or a Horrible Truth? Systematic Review of Gastrointestinal Manifestations of COVID-19. International Monthly Journal in the Field of Hepatology, 20(3). https://doi.org/10.5812/hepatmon.102729

Morens, D. M., Folkers, G. K., \& Fauci, A. S. (2009). What Is a Pandemic? The Journal of 
Infectious Diseases, 200(7), 1018-1021. https://doi.org/https://doi.org/10.1086/644537

Myers, D. G. (2010). Psychology. New York: Worth Publishers.

Neo, P. (2020). Stop COVID-19 Hoarding: Indonesian Police and Philippines Government Order Purchase Limits. (Online), (https://www.foodnavigatorasia.com/Article/2020/03/27/Stop-COVID-19-hoarding-Indonesian-police-andPhilippines-government-order-purchase-limits), diakses pada 28 Februari 2021.

Pawlick, T. F. (2012). The End of Food: How The Food Industry is Destroying Our Food Supply and What You Can Do About It. Vancouver: Greystone Books.

Pelupessy, D. C. (2020). Alasan Psikologi di Balik "Panic Buying." (Online), (https://www.cnnindonesia.com/gaya-hidup/20200322161747-284-485813/alasanpsikologi-di-balik-panic-buying), diakses pada 28 Februari 2021.

Pingit, A. (2020). Panic Buying dan Ancaman Virus Corona Menjangkiti Bisnis Retail. (Online), (https://katadata.co.id/pingitaria/indepth/5e9a421407847/panic-buying-danancaman-virus-corona-menjangkiti-bisnis-retail), diakses pada 28 Februari 2021.

Putri, C. A. (2020). Peritel Blak-Blakan Ada 3 Kali Panic Buying Gegara Corona. (Online), (https://www.cnbcindonesia.com/news/20200320104453-4-146366/peritel-blak-blakanada-3-kali-panic-buying-gegara-corona), diakses pada 28 Februari 2021.

Reuters. (2020). COVID-19: Panic-Buying in Tokyo as Residents Asked to Hunker Down for Weekend. (Online), (https://www.thejakartapost.com/news/2020/03/27/panic-buying-intokyo-as-residents-asked-to-hunker-down-for-weekend.html), diakses pada 28 Februari 2021.

Roberts, J. D., \& Tehrani, S. O. (2020). Environments, Behaviors, and Inequalities: Reflecting on The Impacts of The Influenza and Coronavirus Pandemics. International Journal of Environmental Research and Public Health, 17(12), 4484.

Rosita, R. (2020). Panic Buying in the COVID-19 Pandemic Era in Indonesia. International 
Journal of Multisciences, 1(7), 60-70.

Rossa, V., \& Varwati, L. (2020). Cuma di New York, Panic Buying Anak Ayam di Tengah Pandemi Covid-19.(Online), (https://www.suara.com/lifestyle/2020/03/31/140824/cuma-di-new-york-panic-buyinganak-ayam-di-tengah-pandemi-covid-19?page=all), diakses pada 28 Februari 2021.

Shou, B., Xiong, H., \& Shen, Z. M. (2011). Consumer Panic Buying and Fixed Quota Policy. Management Science, 1-38.

Soenjoto, W. P. P., \& Mujiyono, A. (2020). Fenomena Panic Buying dan Scarcity di Masa Pandemi COVID-19 Tahun 2020 (Kajian secara Ekonomi Konvensional dan Syariah). Jurnal Istiqro: Jurnal Hukum Islam, Ekonomi, dan Bisnis, 6(2), 126-139.

Solahuddin, G. (2020). Wabah Virus Corona Covid-19, di Indonesia Panic Buying Sembako di USA Beli Senjata Api. (Online), (https://health.grid.id/read/352065473/wabah-viruscorona-covid-19-di-indonesia-panic-buying-sembako-di-usa-beli-senjata-api?page=all), diakses pada 28 Februari 2021.

Southey, F. (2020). Panic Buying Amid Coronavirus Fears: How Much are We Spending... and Why is a Problem?. (Online), (https://www.foodnavigator.com/Article/2020/03/27/Panic-buying-amid-coronavirusfears-How-much-are-we-spending-and-why-is-it-a-problem), diakses pada 28 Februari 2021.

Taylor, S. (2019). The Psychology of Pandemics: Preparing for the Next Global Outbreak of Infectious Disease. Newcastle, UK: Cambridge Scholars Publishing.

Wahyudi, S. (2020). Media Baru dan Demokratisasi di Indonesia. Prosiding Seminar dan Konferensi Nasional Ilmu Komunikasi, 137-146. Banten: Universitas Sultan Ageng Tirtayasa.

Wheaton, M. G., Abramoritz, J. S., Berman, N. C., Fabricant, L. E., \& Olatunji, B. O. (2012). 
Psychological Predictors of Anxiety in Response to The H1N1 (Swine Fu) Pandemic. Cognitive Therapy and Research, 36, 210-218. https://doi.org/10.1007 /s10608-0119353-3

WHO. (2020). WHO Director-General's Opening Remarks At the Media Briefing on COVID19 - 11 March 2020. (Online), (https://www.who.int/directorgeneral/speeches/detail/who-director-general-s-opening-remarks-at-the-media-briefingon-covid-19---11-march-2020), diakses pada 28 Februari 2021.

Widyaningrum, G. L. (2020). WHO Tetapkan COVID-19 Sebagai Pandemi Global, Apa Maksudnya? National Geographic Indonesia. (Online), (https://nationalgeographic.grid.id/read/132059249/who-tetapkan-covid-19-sebagaipandemi-global-apa-maksudnya?page=all), diakses pada 28 Februari 2021.

Ye, Y., Jiao, W., \& Yan, H. (2020). Managing Relief Inventories Responding to Natural Disasters: Gaps between Practice and Literature. Production and Operations Management, 29(4), 807-832.

Zingales, L. (2012). A Capitalism for The People: Recapturing The Lost Prosperity. New York: Basic Books.

Zwart, H. (2020). Emerging Viral Threats and The Simultaneity of Tthe Non-Simultaneous: Zooming Out in Times of corona. Medicine, Health Care, and Philosophy, 23(4), 589602. 